\title{
Atypical Suicide Attempt with Jugular Vein Laceration During Adolescence: A Case Report
}

\section{Tentativa de Suicídio Atípica com Laceração da Veia Jugular na Adolescência: A Propósito de um Caso Clínico}

Daniela Cardoso ${ }^{1}$, Rita Gonçalves²

\section{ABSTRACT}

Self-harm is a common finding during adolescence and skin-cutting a frequent method of non-suicidal self-injury. However, suicide attempts with severe neck cutting injuries are infrequently reported. Here, we report in detail the case of an adolescent with no prior psychiatry history or self-harm behaviours who had a first suicide attempt with complete external jugular vein laceration. Careful psychiatric evaluation and history reveal exposure to significant adverse childhood experiences.

Our aim with this case report is to illustrate and discuss the influence of trauma during early childhood and dissociative symptomatology in suicidal behaviour during adolescence.

KEYWORDS: Adolescent; Jugular Veins/injuries; Self-Mutilation; Suicide, Attempted 


\section{RESUMO}

A automutilação é um achado comum durante a adolescência, sendo os cortes da pele um método frequente de autoagressão na ausência de intencionalidade suicida. No entanto, tentativas de suicídio com graves lesões cortantes do pescoço são relatadas com pouca frequência. Aqui, descrevemos em detalhe o caso de um adolescente sem antecedentes psiquiátricos ou comportamentos de automutilação prévios que teve uma primeira tentativa de suicídio com laceração completa da veia jugular externa. Uma avaliação e história psiquiátrica cuidadosa revelam a exposição a experiências adversas significativas na infância. O nosso objetivo neste relato de caso é ilustrar e discutir a influência do trauma durante a infância precoce e a sintomatologia dissociativa no comportamento suicidário na adolescência.

PALAVRAS CHAVE: Adolescente; Automutilação; Tentativa de Suicídio; Veias Jugulares/lesões

\section{INTRODUCTION}

Self-harming behaviours, with or without suicidal intention are frequent and a significant clinical issue during adolescence. Recent data shows an overall lifetime prevalence of direct self-harming behaviours up to $39 \%$ in adolescents in European countries. ${ }^{1}$ Suicide is the second leading cause of death in youth (age 10-24 years) worldwide. ${ }^{2}$

Although skin cutting is a common method of self-harming within adolescents, it is typically related to non-suicidal self-injury, usually without suicidal intention.

A recent meta-analytic review of worldwide suicide rates in adolescence states that hanging/suffocation is the most common method of suicide across all countries and for both sexes, followed by jumping/lying in front of a moving object or jumping from a height ${ }^{3}$ and the proportion of 15- to 24-year-olds who die by cutting/ piercing is around $0.4 \%$. Thus, $99.6 \%$ of youth who die by suicide use methods other than cutting. Those youth who die by cutting generally do so by cutting the carotid artery or jugular vein in the neck, not arms or legs. ${ }^{2}$

Exposure to adverse childhood experiences (ACEs), such as physical and emotional abuse, is a well-established risk factor for self-harm, however, the psychological and biological processes underlying this relationship are unclear. Recent data indicates that there is a strong association between the total number of ACEs and self-harm, with each additional ACE conferring an additional $11 \%$ risk of self-harm at age $16 .{ }^{4}$ Also, childhood maltreatment, specifically pre-adolescent physical abuse is referred to, in the literature, as an independent risk factor for adolescent suicidal behaviour. ${ }^{5}$

To our knowledge, this is the first reported case of attempted suicide with jugular vein and neck cutting in an adolescent in Portugal.

\section{CASE REPORT}

We present the clinical case of a 15-year-old male adolescent, with no previous psychiatric or medical history, who presented at our emergency department unit after a violent suicide attempt by a severe neck cutting injury.

On admission, urgent surgical intervention was required due to profound lesions involving 2/3 of his neck circumference, anterior neck muscles, platysma and complete external jugular laceration. Full medical evaluation, including blood sample analysis and drugs search, was completed. All laboratory tests including complete blood count were in normal limits except for haemoglobin levels due to blood loss. Urine and blood analysis were negative for drugs.

After clinical stabilization, the patient's past personal and family history was obtained by interviewing him and his mother.

His mother confirmed that he did not have any previous suicidal behaviours or any psychiatric medical history.

He states that suddenly, during that day, he started to have some negative thoughts regarding hurting himself and wanting to die. He describes "having a strange feeling" and "not wanting to be here". He went to school and when he got back home, he went through the kitchen for a snack, but when he saw the knife, he rather grabbed it and went to his bedroom. There he made several cuts in his neck, before asking for help from his mother, who was sitting in the next room. He refers that he doesn't know what happened and expresses some perplexity and feeling of depersonalization, without understanding his behaviour. At the moment of admission, he was expressing sincere regret. He states no precipitating factors besides having a query with his recent girlfriend during that day (and the fear of being abandoned by her). He denied that he used any substances. He was not 
on any medication before hospitalization.

In terms of his mental status assessment, his affect was blunt, describing the previous timeline of events with any to no emotionality. His posture was rigid, possibly due to his neck injury and treatment. The speech was organized and fluent. There was no evidence of formal thought disorder, abnormal perceptions of any kind, delusional thinking or passivity phenomena. There was no evidence of suicidal ideation at the time of assessment, ideas of self-harm or harm to others. He showed limited insight into his mental state and precipitating conditions.

No appetite or sleep disturbances were referred. There were no drugs or alcohol consumption history. He had a history of good school performance. This year, he just changed school, to integrate a science class and still had few friends at the moment of admission (the school had started in the previous month). Although he is described by his mother as not having difficulties to socialize, he had no close friends besides his new girlfriend and her group of friends. No developmental delays where found.

Regarding his family history, he was born in Brazil and moved to Portugal when he was 7 years old, to join his mother from whom he was separated since he was 3 years old. During the previous years of his childhood, he lived with his older brother and their father, who is recalled as abusive. During the initial emergency psychiatry assessment, he states an episode of severe maltreatment during his infancy that he vividly recalls. When he turned 7, his mother, who was already living in Portugal, managed to pay a "coyote" to accompany him and his brother on the trip, first to Rio de Janeiro and then to Portugal.

No psychiatric or suicide family history was referred. At the time of the assessment, he lived with his mother, stepfather and older brother, with whom he maintained a good relationship.

Informed consent was obtained from the patient and her parents to publish this case report.

\section{DISCUSSION}

In this article, we present a rare case of a male adolescent with an episode of extreme self-harm behaviour with suicidal intent, no prior self-harm or suicidal behaviours and severe history of childhood abuse and trauma.

Although cutting is a common form of self-harming behaviour during adolescence, severe cutting associated with potentially lethal injuries is infrequently reported.
Literature states that injuries inflicted on the face, eyes, neck in the jugular region, breast or genitals, for instance, may be clinically indicative of greater psychological disturbance than when injuries are inflicted elsewhere. ${ }^{3}$

Common risk factors for suicide attempts include having a previous suicide attempt, being female, having a mood disorder, poor parent-child communication, family pathology or family history of suicidal behaviour. ${ }^{6}$ In this case report, none of these frequently referred risk factors was present.

Nevertheless, our patient presented a significant history of physical and emotional abuse, not only during the first few years of his life, when he was living with his father, but also when he had to travel to the care of a stranger to an unknown country to join a mother he had not seen since he was 3 years old. All these experiences could undoubtedly be classified as ACEs and could have provided an important risk factor to self-harm and suicidal behaviours.

Also, the impact of these early separations on his attachment to his caregivers should not be forgotten - joined her mother at age 7, after not seeing her since he was 3 years old, lived with his abusive father until age 7 and never saw him again. Difficulties in attachment are not only highly related to suicidal behaviours ${ }^{3,4}$ ), but they impact future patterns of interpersonal relationships. His attachment difficulties may justify the fear of being abandoned by his girlfriend, which he felt immediately, as a consequence of a brief discussion.

On the other hand, childhood neglect or traumatic events are frequently related to dissociative symptoms, like those presented by our patient. ${ }^{5}$ The flattened affect, lack of emotionality in describing the event, feelings of depersonalization, the sense of being detached from himself, high tolerance to pain, and lack of control over his body and actions are symptoms compatible with dissociative disorders.

Physical dissociation, characterized as detachment and alienation from one's body, can serve as a facilitating precursor to the actual self-harm. Two facets of physical dissociation are insensitivity to bodily cues and tolerance to physical pain ${ }^{6}$ which can provide the analgesia necessary for an aggressive and potentially deadly cutting behaviour in an adolescent.

Considering the information discussed above, this case emphasizes the importance of being aware of the role of childhood trauma and dissociative symptoms in the clinical assessment of self-harm and suicidal behaviours in adolescents. 


\section{WHAT THIS CASE REPORT ADDS:}

- Self-inflicted cuts with large blood vessel laceration are uncommon methods for attempted suicide during adolescence.

- Dissociative symptoms are not uncommon in adolescence and should be assessed in all young people, especially those with a previous history of trauma.

- Dissociative symptoms are related to higher tolerance to physical pain and can be described during severe suicide attempts.

- Inquiry about abusive and traumatic experiences should be included in the routine assessment of adolescents with attempted suicide.

CONFLITOS DE INTERESSE: Os autores declaram não ter qualquer conflito de interesse na realização do presente trabalho.

FONTES DE FINANCIAMENTO: Não houve qualquer fonte de financiamento na realização do presente trabalho.

CONFIDENCIALIDADE DOS DADOS: Os autores declaram ter seguido os protocolos da sua instituição acerca da publicação dos dados de doentes.

CONSENTIMENTO: Consentimento do doente para publicação obtido.

PROVENIÊNCIA E REVISÃO POR PARES: Não comissionado; revisão externa por pares.

CONFLICTS OF INTEREST: The authors declare that they have no conflicts of interest.

FINANCIAL SUPPORT: This work has not received any contribution, grant or scholarship.

CONFIDENTIALITY OF DATA: The authors declare that they have followed the protocols of their work center on the publication of data from patients.

PATIENT CONSENT: Consent for publication was obtained.

PROVENANCE AND PEER REVIEW: Not commissioned; externally peer reviewed.

\section{REFERENCES}

1. Brunner R, Kaess M, Parzer P, Fischer G, Carli V, Hoven CW, et al. Life-time prevalence and psychosocial correlates of adolescent direct self-injurious behavior: a comparative study of findings in 11 European countries. J Child Psychol Psychiatry. 2014;55:337-48. doi: 10.1111/jcpp.12166.

2. Walsh BW. Treating self-injury : a practical guide. 2nd ed. New York: The Guilford Press A Division of Guilford Publications;2012.

3. Brodsky BS. Early Childhood Environment and Genetic Interactions: the Diathesis for Suicidal Behavior. Curr Psychiatry Rep. 2016;18:86. doi: 10.1007/s11920-016-0716-z.
4. Cohen LJ, Ardalan F, Yaseen Z, Galynker I. Suicide Crisis Syndrome Mediates the Relationship Between Long-term Risk Factors and Lifetime Suicidal Phenomena. Suicide Life Threat Behav. 2018;48:613-23. doi: 10.1111/sltb.12387.

5. Jonsson PV. Complex trauma, impact on development and possible solutions on an adolescent intensive care unit. Clin Child Psychol Psychiatry. 2009;14:437-54. doi: 10.1177/1359104509104051.

6. Levinger S, Somer E, Holden RR. The importance of mental pain and physical dissociation in youth suicidality. J Trauma Dissociation. 2015;16:322-39. doi:10.1080/15299732.2014.989644 